\title{
PELIMPAHAN HUTANG TERHADAP AHLI WARIS MENURUT PASAL 833 AYAT (1) KUHPERDATA (Analisis Perspektif Hukum Islam)
}

\author{
Syuhada \\ Institut Agama Islam Bani Fattah Jombang, Indonesia \\ Syuhada@,iaibafa.ac.id
}

\begin{abstract}
Abstrak: Rumusan pasal 833 KUHPerdata hanya menyebutkan harta warisan sedangkan dalam pasal 1100 KUH Perdata disebutkan bahwa "ahli waris yang telah menerima warisan dituntut dalam hal pembayaran hutang, hibah, wasiat dan beban-beban lain, menanggung bagian yang seimbang dengan apa yang diterima masing-masing.masing-masing dari warisan". Dengan demikian, ahli waris yang menerima warisan dari pewaris tidak hanya berhak atas hartanya, tetapi juga memiliki kewajiban untuk menanggung hutang pewaris. Penelitian ini menggunakan jenis penelitian kepustakaan yaitu penelitian dengan menggunakan upaya pencarian dokumen atau perpustakaan berdasarkan bukubuku, buku-buku dan lain-lain yang relevan dengan permasalahan yang berkaitan dengan skripsi ini. Penelitian ini juga merupakan penelitian kuantitatif, yaitu penelitian yang mengungkapkan suatu fenomena tertentu dengan cara menggambarkan kenyataan yang sebenarnya, dibentuk dengan kata-kata berdasarkan teknik pengumpulan dan analisis data yang relevan, bukan berupa angka dan statistik. Dalam hal ini, data penelitian yang terdapat dalam
\end{abstract}


KUHPerdata, data teori hukum waris dalam Islam, data gambaran umum utang dan data yang berkaitan dengan pengalihan utang. Penolakan untuk menerima warisan sama dengan penolakan untuk menanggung beban hutang pewaris. Dalam KUHPerdata memberikan pilihan kepada ahli waris, salah satunya adalah penolakan untuk menerima warisan. Dengan demikian, sikap ini berprasangka buruk untuk menghindari pengalihan utang ahli waris kepada ahli waris. Sedangkan dalam hukum Islam dikenal dengan istilah transfer hutang (hiwalah). Prinsipnya dari semua pihak tidak ada yang dirugikan.

Kata Kunci: Pengalihan Hutang, Ahli Waris, Pasal 833 ayat (1) KUHPerdata, Hukum Islam

\section{Pendahuluan}

Kematian seseorang mengakibatkan suatu peralihan atas hak dan kewajiban yang dimiliki selama hidupnya kepada para ahli waris. Para ahli waris segera pada saat meninggalnya pewaris mengambil alih hak-hak dan kewajibannya. Dengan demikian ahli waris menggantikan atau meneruskan kedudukan pewaris yang kaitannya dengan harta benda dalam bidang hukum kekayaan.

Menurut pasal 833 KUHPerdata dinyatakan bahwa "sekalian ahli waris dengan sendirinya karena hukum memperoleh hak milik atas segala barang, segala hak dan segala piutang yang si meninggal". Perumusan pasal 833 KUHPerdata tersebut hanya menyebutkan aktivanya saja dari warisan sedangkan dalam pasal 1100 KUHPerdata dinyatakan bahwa "para ahli waris yang telah menerima warisan diwajibkan dalam hal pembayaran hutang, hibah, wasiat dan lain-lain beban, memikul bagian yang seimbang dengan apa yang diterima masing-masing dari warisan". Dengan demikian maka para ahli waris yang menerima warisan dari pewaris tidak saja berhak atas aktivanya saja tetapi mempunyai kewajiban memikul hutang pewaris.

Tidak semua hak dan kewajiban pewaris dan beralih kepada ahli waris, ada beberapa hak dan kewajiban yang tidak dapat beralih karena pewarisan antara lain:

1. Hak atas pemakaian/penggunaan dan mendiami atau penempatan (gebruike en bewoning), juga hak orang tua atas nikmat hasil (oudelijk recht op vruchgenot), demikian pula perjanjian kerja/perburuhan (arbiedovereekomst) dengan meninggalkan karyawan yang bersangkutan selanjutnya tidak beralih kepada ahli warisnya. Ini disebabkan adanya 
sifat hak yang melekat pada seorang semata-mata pribadi (boogstpersoonlijkrechten).

2. Hak atas pakai/atas hasil manfaat (vurchtgebruik) dari data selama hak itu dipunyai oleh pewaris semasa hidupnya, yang menurut undangundang hak dan kewajiban mengenai ini gugur/berakhir karena kematian (pasal 1612, 1646, 1651, 1664, 1813, KUHPerdata). ${ }^{1}$

3. Hak dan kewajiban seseorang yang telah mengadakan perjanjian tidak selalu beralih kepada ahli warisnya, apabila isi perjanjian itu dapat disimpulkan atau secara tegas ditentukan, bahwa memang hak dan kewajiban itu tidak akan beralih demikian (pasal 1381 KUHPerdata). ${ }^{2}$

Orang-orang yang dipanggil oleh Undang-Undang atau wasiat atau keduanya untuk menerima harta peninggalan dapat keluar dari kelompok ahli waris dengan menolak harta peninggalan. Dengan demikian ia melepaskan aktiva dan membebaskan diri dari pasiva. ${ }^{3}$ Jadi ia dianggap tidak pernah sebagai ahli waris dan tidak ada sangkut pautnya dengan harta peninggalan. Dalam hubungannya dengan hukum kewarisan terdapat berbagai pandangan, mengingat berbagai pernyataan para ahli hukum diantaranya bahwa hukum kewarisan yang berlaku untuk warga Negara Indonesia. Bagi warga Negara asli pada pokoknya berlaku hukum adat yang berbeda-beda dalam berbagai daerah dan sangat erat hubungannya dengan macam-macam sifat kekeluargaan patrilineal, matrilineal ataupun parental. Oleh karena orang Indonesia tunduk kepada hukum adat itu sebagian besar adalah beragama Islam, maka bagian yang paling besar ini tidak dapat diabaikan begitu saja akibat pengaruh dan peraturan kewarisan yang terdapat di dalam hukum Islam, selama tidak bertentangan dengan syari'at islam. ${ }^{4}$

Hukum kewarisan dalam Islam mendapat perhatian besar, karena pembagian warisan sering menimbulkan akibat-akibat yang tidak menguntungkan bagi keluarga yang ditinggal mati pewarisnya. Naluriah manusia yang menyukai harta benda tidak jarang memotivasi seseorang untuk menghalalkan berbagai cara untuk mendapatkan harta benda tersebut, termasuk didalamnya terhadap harta peninggalan pewarisnya sendiri. Kenyataan demikian telah ada dalam sejarah umat manusia

\footnotetext{
${ }^{1}$ Komar Andasamita, Notaries III Hukum Harta Perkawinan dan Waris, (Ikatan Notaris Indonesia Daerah Jawa Barat, 1987), hal. 149.

${ }^{2}$ Ibid., hal. 149.

3 A. Pilto, Hukum Waris, Menurut Kitab Undang-Undang Hukum Perdata Belanda, Jilid II, dialih bahasakan oleh M. Isa Arief, (Jakarta : PT. Intermasa,1986), hal. 40.

${ }^{4}$ Imam Muchlas, Waris Mewaris dalam Islam, cet. I, hal. 2, (Pasuruan : PT. Garoeda Buana Indah, 1996), hal. 3. dikutip dari Sayuti Thalib, Hamid Farihi, Pembabaruan Hukum Kewarisan Islam di Indonesia, Studia Islamika,(Jakarta : 18 Nopember 1983), hal. 21.
} 
hingga sekarang ini. Terjadinya kasus-kasus gugat waris di pengadilan, baik pengadilan agama maupun pengadilan negeri menunjukkan fenomena ini. ${ }^{5}$ Bahkan, turunnya ayat-ayat al-Qur'an yang mengatur pembagian harta warisan yang menunjukkannya bersifat qat'i al-dalälah adalah merupakan refleksi sejarah dari adanya kecenderungan materialistis umat manusia, disamping sebagai rekayasa sosial terhadap sistem hukum yang berlaku di masyarakat. ${ }^{6}$

Dalam ilmu hukum Islam, hukum waris Islam dikenal dengan istilah farä'id, yaitu masalah-masalah pembagian harta warisan. Kata alfaräid ini adalah bentuk jamak dari al-farị̣ah yang bermakna al-mafrüdah atau sesuatu yang diwajibkan. Atau diartikan juga pembagian yang telah ditentukan kadarnya. ${ }^{7}$ Sedangkan menurut bahasa, lafal al-farị̂lah diambil dari kata al-fard atau kewajiban yang memiliki 2 (dua) makna, yaitu:

a. Secara Etimologis, diantaranya sebagai berikut:

1) Al-qat', yaitu ketetapan atau kepastian;

2) At-taqdir, yaitu suatu ketentuan;

3) Al-inzal, yaitu menurunkan;

4) At-tabyin, yaitu penjelasan;

5) Al-iblal, yaitu menghalalkan;

6) Al-'ata', yaitu pemberian;

Keenam arti tersebut dapat digunakan seluruhnya karena ilmu farä’ị meliputi beberapa bagian kepemilikan yang telah ditentukan secara tetap dan pasti. Selain itu, penjelasan Allah SW'T tentang setiap ahli waris yang menerima bagiannya masing-masing, semuanya merujuk pada sebutan atau penamaan ilmu faräị̈. ${ }^{9}$ Secara Terminologis, ada beberapa definisi ilmu farä’ị yaitu sebagai berikut:

1) Penetapan kadar warisan bagi ahli waris berdasarkan ketentuan syara'yang tidak bertambah, kecuali dengan radd (yaitu mengembalikan sisa lebih kepada para penerima warisan), dan tidak berkurang, kecuali dengan 'aül (yaitu pembagian harta waris, dimana jumlah bagian paraahli waris lebih besar dari pada asal masalahnya, sehingga harus dinaikkan menjadi sebesar jumlah bagian-bagian itu);

2) Pengetahuan tentang pembagian warisan dan tata cara menghitung yang terkait dengan pembagian harta waris dan pengetahuan tentang

\footnotetext{
${ }^{5}$ Akhmad Rofiq “Hukum Islam di Indonesia”, cetakan 3,(Jakarta: PT.Grafindo, 1998), hal. 355.

${ }^{6}$ Ibid., hal. 355.

${ }^{7}$ Komite Fakultas Syariah Universitas Al-Azhar Mesir, Hukum Waris Islam, Jakarta: Senayan Abadi Publishing, 2004), hal. 11.

${ }^{8}$ Ibid, hal. 12 s.d 13.

${ }^{9}$ Ibid, hal. 13.
} 
bagian yang wajib dari harta peninggalan untuk setiap pemilik hakwaris;

3) Disebut juga dengan fiqh al-mawäris (fikih tentang warisan) dan tata cara menghitung harta waris yang ditinggalkan;

4) Kaidah-kaidah fiqih dan cara menghitung untuk mengetahui bagian setiap ahli waris dari harta peninggalan. Termasuk juga dalam definisi ini adalah mengenai batasan-batasan dan kaidah-kaidah yang berkaitan erat dengan keadaan ahli waris, dan hal-hal yang erat hubungannya dengan cara menyelesaikan pembagian harta waris, serta siapa saja yang terhalang mendapatkan warisan;

5) Disebut juga dengan ilmu yang digunakan untuk mengetahui ahli waris yang dapat mewarisi dan yang tidak dapat mewarisi serta mengetahui kadar bagian setiap ahli waris. ${ }^{10}$

Secara garis besar ilmu faräị mencakup 3 (tiga) unsur penting, yaitu:

a) Pengetahuan tentang kerabat-kerabat yang menjadi ahli waris;

b) Pengetahuan tentang bagian setiap ahli waris; dan

c) Pengetahuan tentang cara menghitung yang dapat berhubungan dengan pembagian harta waris. ${ }^{11}$

Adapun harta peninggalan mayit disebut Tirkah menurut bahasa, adalah sesuatu yang ditinggalkan dan disisakan oleh seseorang. Sedangkan tirkah menurut istilah adalah seluruh yang ditinggalkan mayit berupa harta dan hak-hak yang tetap secara mutlak. ${ }^{12}$ Dengan demikian, tirkah mencakup 4 (empat) hal, yaitu:

1) Kebendaan, berupa benda-benda bergerak dan benda-benda tetap.

2) Hak-hak yang mempunyai nilai kebendaan, antara lain seperti hak monopoli untuk mendayagunakan dan menarik hasil dari suatu jalan, sumber air minum, dan sebagainya. Termasuk juga hak kemanfaatan, yang antara lain seperti memanfaatkan barang yang disewa dan dipinjam.

3) Sesuatu yag dilakukan oleh mayit sebelum ia meninggal dunia, seperti jerat yang menghasilkan binatang buruan setelah ia meninggal dunia.

\footnotetext{
${ }^{10}$ Ibid, hal. 13.

${ }^{11}$ Ibid, hal. 13.

${ }^{12}$ Ibid, hal. 67.
} 
4) Diyat (denda) yang dibayarkan oleh pembunuh yang melakukan pembunuhan karena khilaf. ${ }^{13}$

Tirkah juga diartikan sebagai sesuatu yang ditinggalkan oleh mayit, berupa harta, diyat yang diambil dari pembunuhnya, juga termasuk di dalamnya berupa hak seperti hak khiyar, syuf'ah, dan lain-lain. ${ }^{14}$ Menurut T. M. Hasbi Ash Shiddieqy, ada beberapa hal yang harus diperhatikan sebelum mempermasalahkan mengenai hak-hak yang berkaitan dengan tirkah ini, yaitu:

1) Kepemilikan seseorang atas harta benda semasa hidupnya yang dimiliki seorang manusia ketika dia hidup dan ditinggalkannya setelah dia meninggal dunia diantaranya dapat berupa harta yang terdiri dari harta dalam bentuk benda yang tidak bergerak seperti tanah, sawah, kebun, maupun harta dalam bentuk benda yang bergerak seperti kendaraan dan sebagainya. ${ }^{15}$ Selain harta, ada juga berupa hak yang sifatnya bermacam-macam, seperti:

a) Hak yang bersifat harta

Yaitu hutang-hutang yang belum dibayar oleh piutang dan seperti diyat (denda atau ganti rugi) sebagai pengganti jiwa atau irsy sebagai pengganti anggota.

b) Hak yang mengandung makna harta

Yaitu hak menetap disuatu bidang tanah yang dikhususkan untuk pembinaan dan penanaman.

c) Hak yang mengikuti harta

Yaitu hak untuk mempergunakan jalan dan memanfaatkannya, serta hak yang tidak ada unsur hartanya seperti hak memelihara anak kecil, hak mewilayahi diri dan harta, dan juga seperti hak mentalak isteri dan hak qishash.

d) Hak yang mempunyai dua Syäbah (kemiripan), yaitu:

- Syäbah dengan hak-hak harta kehartaan.

- Syäbah dengan hak-hak kepribadian, yaitu bukan semata-mata hak yang bersifat harta dan bukan pula hak yang semata-mata bersifat pribadi, seperti hak piutang dalam menangguhkan hutang yang masih dalam tanggung jawabnya, dan juga seperti hak syuf'a $b^{16}$,

${ }^{13}$ Ibid, hal. 68.

${ }^{14}$ Ibid, hal. 68.

${ }^{15}$ Ibid, hal. 23 s.d. 25.

16 M. Idris Ramulyo, Perbandingan Pelaksanaan Hukum Kewarisan Islam dengan Kewarisan menurut Hukum perdata (BW), edisi kedua, cetakan kedua, (Jakarta : Sinar Grafika, 2000), hal. 108. 
kbiyar ${ }^{17}$ syarath dan kbiyar ru'yah. Mengenai hak-hak yang mempunyai dua Syābah ( dua rupa yang satu mirip kesana dan yang satu mirip kemari) ini, para ulama mempunyai pendapat yang berbeda. Ulama, salah satunya adalah Jumhur ulama, yang menyatakan unsur kehartaan atas unsur kepribadian menetapkan bahwa hak-hak itu dipusakai dan berpindah kepada para waris. Sedangkan ulama, seperti Golongan Hanafiyah dan Ibnu Hazm, yang menyatakan segi kepribadian atas unsur kehartaan berpendapat bahwa hak-hak itu tidak diwarisi dan tidak berpindah kepada waris. Karenanya hak syuf'ah, khiyar syärat, dan khiyar ru'yah tidak berpindah kepada waris. ${ }^{18}$

2) Berpindahnya Kepemilikan Seorang Pewaris Kepada Para Pewarisnya Mengenai pindahnya segala sesuatu yang dimiliki oleh muwāis ini, semua ulama mempunyai pendapat yang sama, yaitu menetapkan bahwa segala yang dimiliki oleh muwārï atau seseorang yang mati dengan meninggalkan harta pusaka dimasa hidupnya, baik harta yang bergerak, maupun harta yang tidak bergerak, demikian pula hak-hak kehartaan, akan diwarisi oleh parapewaris sesudah meninggalnya dan berpindahlah harta itu kepada para waris dengan jalan pusaka. Mereka juga sepakat bahwa yang dimiliki oleh muwàris semasa hidupnya yang merupakan hak-hak kepribadian, tidaklah dipusakai dan tidaklah pindah kepada orang lain dengan jalan pusaka. ${ }^{19}$

Adapun mengenai manfaat-manfaat yang menjadi hak dari yang meninggal, maka Jumhur Fuqaha menyatakan bahwa hal tersebut diwariskannya kepada para waris, karena dihitung harta, sedang Golongan Hanafiyah berpendapat tidak mewariskannya, baik manfaatmanfaat itu dimiliki dengan jalan'iwad, seperti rumah yang disewa, ataupun bukan dengan jalan iwad seperti sesuatu yang diwasiatkan. Pendapat para Jumhur Fuqaha dalam masalah ini, adalah pendapat yang kuat dan layak diamalkan, karena sesuatu yang dengan 'uruf manusia dan adat istiadat. ${ }^{20}$

17 Ibid., hal. 108.

18 Ibid., hal. 108.

19 T.M. Hasbi Ash Shiddieqy, Fiqhul Mawaris (Hukum-Hukum Warisan Dalam Syari'at Islam), (Jakarta : Bulan Bintang, 1973), hal. 24.

20 Syuhada. (2020). PENERAPAN BAGIAN WARISAN ANAK PEREMPUAN DAN CUCU: (Studi kasus KHI pasal 176). Tafáqquh: Jurnal Penelitian Dan Kajian Keislaman, 8(2), 286-301 


\section{Hak dan Kewajiban yang Berkaitan dengan Harta Peninggalan Pewaris}

Berkaitan dengan tirkah ada beberapa hak yang harus dipenuhi secara tertib sehingga apabila hak yang pertama, atau yang kedua menghabiskan segala tirkah, tidaklah lagi berpindah kepada hak-hak yang lain. Hak-hak yang berkaitan dengan tirkah selain dari pada hak pusaka ada 2 (dua) hal, yaitu:

1) Hak-hak yang harus didahulukan sebelum para waris menerima bahagiannya;

2) Hak-hak yang harus dikemudiankan dari pembahagian harta pusaka apabila ada waris.

Adapun hak-hak yang harus didahulukan dan harus dilaksanakan secara tertib sebelum para waris menerima bahagiannya adalah: Hak yang pertama, Pentajbizan mayyit yang meninggalkan harta dan pentajbizan mayit orang yang wajib dinafkahi oleh mayit yang meninggalkan harta itu. Maka hak inilah yang harus diambil dari jumlah tirkah sebelum diambil hak-hak yang lain. Apabila orang meninggal tidak mempunyai harta maka tajbiznya itu dipikul oleh kerabat-kerabat yang wajib menafkahinya. Jika tidak ada yang wajib menafkahinya, atau ada tetapi fakir, maka tajhiznya dipikul oleh Baitul Mal. Kalau Baitul Mal tidak dapat mengeluarkan keperluan tajhiznya, maka wajiblah dipikul oleh hartawan-hartawan Islam dan menjadi fardu kifayablah atas mereka. ${ }^{21}$

Hak yang kedua, Hutang yang harus dibayar oleh orang yang meninggal. Untuk keperluan membayar hutang diambil dari pada tirkah, sesudah diambil keperluan-keperluan tajhiz. Menurut pendapat Jumbur Fuqaha, bahwasanya hutang-hutang pada Allah tidaklah gugur karena matinya orang yang belum membayar hutangnya, dan wajiblah hutanghutang itu ditunaikan sebelum menunaikan wasiatnya, walaupun tidak diwasiatkan untuk membayarnya. Menurut pendapat golongan Hanafiyah, hutang-hutang pada Allah seperti hutang zakat, kafarat, dan nazar, tidak diambil dari tirkah. Walaupun Jumbur Fuqaha sependapat dalam menetapkan bahwa hutang-hutang daripada Allah diambil dari tirkah dan didahulukan atas wasiat, namun mereka berbeda pendapat dalam tertib penunaiannya. ${ }^{22}$ Ada pula yang mengatakan bahwa:

a) Hutang-hutang pada Allah didahulukan atas hutang-hutang pada sesama manusia. Demikianlah mazhab syafi'iyah dan adludh-dhabir,

b) Hutang-hutang pada Allah dikemudiankan dari hutang pada semua manusia. Inilah madz̧ab malikiyab;

\footnotetext{
${ }^{21}$ Ibid., hal. 27.

${ }^{22}$ Ibid., hal. 28.
} 
c) Hutang pada Allah dan hutang pada hamba yang tidak berpautan dengan benda, sama derajatnya dalam menunaikannya (membayarnya), dan dia dikemudiankan dari hutang pada sesama hamba yang berpautan dengan benda. Inilah pendapat golongan Hambaliyah. $^{23}$

Hak yang ketiga, Hak menunaikan wasiat yang diwasiatkan oleh orang yang meninggal diwaktu dia masih hidup dalam batas yang dibenarkan syara' tanpa perlu persetujuan para warits, yaitu tidak lebih dari sepertiga harta peninggalan, sesudah diambil keperluan tajhiz dan keperluan membayar hutang, baik wasiat itu, untuk waris, ataupun untuk orang lain. Adapun yang dimaksud dengan wasiat ialah memilih sesuatu kepada orang yang dipautkan kepada meninggalnya yang memilih itu, tanpa ada imbalan apa-apa baik yang diwasiatkan itu merupakan benda, ataupun berupa ma'rifat. ${ }^{24}$

Hak yang keempat, Hak ini merupakan pusaka yang dimiliki oleh para waris. Apabila masih ada sisa harta, sesudah diambil keperluan tajhiz, keperluan membayar hutang dan washiyat, maka sisa itu menjadi hak waris yang mereka membahaginya menurut ketentuan syara' sendiri. ${ }^{25}$

\section{Pewaris dan Dasar Hukum Mewaris}

Pewaris, yang dalam literatur fikih disebut al-muwarris, ialah seseorang yang telah meninggal dunia dan meninggalkan sesuatu yang dapat beralih kepada keluarganya yang masih hidup. ${ }^{26}$ Berdasarkan prinsip bahwa peralihan harta dari pewaris kepada ahli waris berlaku sesudah matinya pewaris, maka kata "pewaris" itu sebenarnya tepat untuk pengertian seseorang yang telah mati. Atas prinsip asas ijbāri maka pewaris itu menjelang kematiannya tidak berhak menentukan siapa yang akan mendapatkan harta yang ditinggalkannya itu, karena semuanya itu telah ditentukan secara pasti oleh Allah. Kemerdekaannya untuk bertindak atas harta itu terbatas pada jumlah sepertiga dari hartanya itu. ${ }^{27}$

Dasar dan sumber utama dari hukum Islam, sebagai hukum agama (Islam) adalah nash atau teks yang terdapat dalam al-Qur'an dan sunnah Nabi. Adapun yang menjadi dasar hak untuk mewaris atau dasar untuk mendapat bagian harta peninggalan menurut Ayat-ayat al-Qur'an. ${ }^{28}$

\footnotetext{
${ }^{23}$ Ibid., hal. 28.

${ }^{24}$ Ibid., hal. 30.

${ }^{25}$ Ibid., hal. 31.

${ }^{26}$ Amir Syarifuddin, HukumKewarisan Islam, (Jakarta : Kencana, 2008), hal. 204.

${ }^{27}$ Ibid., hal. 204.

${ }^{28}$ Fachrodin, F. (2019). Fungsi Hukum dalam Pembangunan Ekonomi. Tafáqqub: Jurnal Penelitian Dan Kajian Keislaman, 7(1), 114-138.
} 


\section{Ahli Waris}

Ahli waris adalah sekumpulan orang atau seorangatau individu atau kerabat-kerabat atau keluarga yang ada hubungan keluarga dengan si meninggal dunia dan berhak mewarisi atau menerima harta peninggalan yang ditinggal mati oleh seseorang (pewaris). ${ }^{29}$ Secara garis besar golongan ahli waris di dalam Islam dapat dibedakan ke dalam 3 (tiga) golongan, yaitu ahli waris menurut al-Qur'an atau yang sudah di tentukan di dalam al-Qur'an disebut żul farä’ị, ahli waris yang ditarik dari garis ayah, disebut 'așabah dan ahli waris menurut garis ibu, disebut $\dot{z} u l$ arham. ${ }^{30}$ a. Żaul Furuẹ ('aṣhābul Furūẹ):

Adalah orang-orang yang menerima warisan tertentu pada waktu tertentu. ${ }^{31}$ Definisi lainnya menyebutkan bahwa żaul Furud adalah mereka yang mempunyai bagian dari keenam bagian yang ditentukan bagi mereka, yaitu: 1/2,1/4,1/8, 2/3,1/3 dan 1/6. żaul Furuḍ ada dua belas orang: empat laki-laki, yaitu ayah, kakek yang sah dan seterusnya ke atas, saudara laki-laki seinu, dan suami. Dan delapan perempuan, yaitu isteri, anak perempuan, saudara perempuan sekandung,saudara perempuan seayah, saudara perempuan seibu, anak perempuan dari anak laki-laki, ibu, dan nenek serta seterusnya sampai ke atas. ${ }^{32}$

b. 'așabah

Yaitu sekumpulan orang-orang laki-laki dalam 'așabah yang mewarisi harta peninggalan. Pengertian 'așabah semula berasal dari 'Așabat, yang semula berarti semua anggota laki-laki dalam usbah yang kemudian menimbulkan tambahan pengertian dengan 'așabah bi'l-gairi, sedangkan semula hanya 'aṣabab binafși.

1) 'așabah Binafsi

Ialah orang yang menjadi 'așabah dengan sendirinya secara otomatis, misalnya:

a) Anak laki-laki,

b) Anak laki-laki dari anak laki-laki, bila tidak ada lagi anak lakilaki yang masih hidup,

\footnotetext{
${ }^{29}$ M. Idris Ramulyo, Perbandingan Pelaksanaan Hukum Kewarisan Islam dengan Kewarisan menurut Hukum perdata (BW), edisi kedua, cetakan kedua,... hal. 103.

30 Eman suparman, "Hukum Waris Indonesia", (Bandung : PT. Refika Aditama, 2007), hal. 17.

31 M. Idris Ramulyo, Perbandingan Pelaksanaan Hukum Kewarisan Islam dengan Kewarisan menurut Hukum perdata (BW) edisi kedua, cetakan kedua.... hal. 103.

hal. 106.

32 Otje Salman dan Mustofa Haffas, Hukum Waris Islam,(Bandung : Refika Aditama, 2001), hal 52.

${ }^{33}$ Ibid., hal. 52.
} 
c) Bapak dalam hal kalalah atau punah (tidak ada anak beserta keturunannya beserta walad),

d) Datuk atau bapak dari bapak dalam hal tidak ada anak-anak beserta keturunannya yang laki-laki. ${ }^{34}$

2) 'așabah bi'l-gairi

Ialah orang-orang yang menerima harta peninggalan itu semula sebagai żaul furud, kemudian menjadi ‘șabah karena ada orang lain. Misalnya anak perempuan yang semula berstatus sebagai żaul furud, menjadi 'așabah karena didamping oleh anak laki-laki. ${ }^{3.5}$

3) 'așabah ma’al-gairi

Yaitu orang-orang yang menerima harta peninggalan itu semula sebagai żaul furud, karena mewaris beserta orang lain maka ia menjadi 'așabah ma'al-gairi. Misalnya saudara perempuan kandung atau sebapak semula berfungsi dan menerima harta peninggalan sebagai żaul furud, dalam hal mati punah atau tidak berketurunan (kalalah) bapak pun sudah meninggal pula (menurut syafi'i) dan bapak beserta datuk telah meninggal pula lebih dahulu dari pewaris (menurut ajaran kewarisan Hanafi), tetapi bila didampingi oleh saudara laki-laki kandung atau sebapak, maka statusnya sebagai żaul furud itu naik derajatnya menjadi 'așabah ma'al gairi atau mendapat warisan sisa dari harta peninggalan. ${ }^{36}$

c. Żul arham

Ialah orang-orang yang mempunyai hubungan darah dengan si pewaris melalui garis ibu atau wanita. Dalam arti luas lagi, maka dzawu'larhaam ialah setiap orang yang ada hubungan darah dengan pewaris, tetapi bukan żaul furud, bukan pula 'așabah bil-gairi dan bukan juga 'aṣabah ma'al-gairi. ${ }^{37}$

\section{Konsep Pelimpahan hutang}

\section{a. Hiwālah}

Hiwallah adalah pengalihan hutang dari orang yang berhutang kepada orang lain yang wajib menanggungnya. Dalam istilah para ulama, hal ini merupakan pemindahan beban utang dari mübil (orang yang berutang)

\footnotetext{
${ }^{34}$ Ibid., hal. 52.

35 Ibid., hal. 53.

36 Ibid., hal. 53.

${ }^{37}$ Ibid., hal. 53.
} 
menjadi tanggungan mühal 'alaih atau orang yang berkewajiban membayar hutang. ${ }^{38}$

Menurut hakikatnya, biwālah merupakan penukaran piutang dengan piutang yang lain. Menurut qaul yang aṣāh, hiwälah ini dkecualikan dari jenis penjualan piutang dengan piutang karena adanya hajat.

Ditinjau dari segi obyeknya biwālah dibagi 2, yaitu : ${ }^{39}$

1) Hiwälah al-Haqq (pemindahan hak)

Hiwalah haqq adalah pemindahan piutang dari satu piutang kepada piutang yang lain atau pemindahan hak untuk menuntut hutang. Dalam hal ini yang bertindak sebagai muhil adalah pemberi hutang dan ia mengalihkan haknya kepada pemberi hutang yang lain sedangkan orang yang berhutang tidak berubah atau berganti, yang berganti adalah piutang. Ini terjadi piutang A mempunyai hutang kepada piutang B.

2) Hiwalab ad-Dain (pemindahan hutang)

Hiwälah ad-dain adalah pemindahan hutang kepada orang lain yang mempunyai hutang kepadanya. Ini berbeda dari hiwālah haqq, karena pengertiannya sama dengan hiwālah yang telah diterangkan di depan yakni yang dipindahkan itu kewajiban untuk membayar hutang. ${ }^{40}$ Rasulullah memberitahukan kepada orang yang mengutangkan, jika yang berutang meng-hiwälah-kan kepada orang yang kaya/mampu, hendaklah ia menerima hiwälah tersebut dan hendaknya ia menagih kepada orang yang di-biwälab-kan (mühal 'alaibi). Dengan demikian, hanya dapat terpenuhi. ${ }^{41}$

Sebagian ulama berpendapat bahwa perintah untuk menerima hiwālah dalam hadist tersebut menunjukkan wajib. Oleh sebab itu, wajib bagi orang mengutangkan (mühal) menerima hiwälah. Adapun mayoritas ulama berpendapat bahwa perintah itu menunjukkan sunnah. Jadi, sunnah hukumnya menerima biwwälah bagi mühal. ${ }^{42}$

\section{b. Dāman (Jaminan)}

Dāman (Jaminan) ialah mengumpulkan suatu tanggungan kepada tanggungan yang lain. Yang lebih baik dikatakan, deman (jaminan) ialah menyanggupi hak orang lain, sehingga hal itu dapat mencakup mendatangkan orang yang berkewajiban melunaskan hak orang lain., jika

\footnotetext{
38 Sayyid Sabiq, Fiqih Sunnah, alih bahasa Nor Hasanuddin, cet. I, jilid. 4. (Surabaya:CV. Bina Iman, 1995), hal. 223.

39 http://id.shvoong.com/humanities/religion-studies/2148108-macam-macamhiwālah/\#ixzz20kat4yur, diakses 21 Agustus 2012.

40 http://id.shvoong.com/humanities/religion-studies/2148108-macam-macamhiwālah/\#ixzz20kat4yur, diakses 21 Agustus 2012.

${ }^{41}$ Sayyid Sabiq, Fiqih Sunnah, alih bahasa Nor Hasanuddin, cet. I, jilid. 4... hal 223.

42 Ibid, hal. 224.
} 
ia menyanggupinya. Orang yang menjamin itu dinamakan d̦amin, damin, kafil, za'im dan bamil. ${ }^{43}$

\section{c. Al-Kafālah (Tanggungan)}

Al-kafälab merupakan jaminan yang diberikan oleh penanggung (käfil) kepada pihak ketiga untuk memenuhi kewajiban pihak kedua atau yang ditanggung. Dalam pengertian lain, kafälah juga berarti mengalihkan tanggung jawab seseorang yang dijamin dengan berpegang pada tanggung jawab orang lain sebagai jaminan.

Dalil yang membolehkan akad al-kafälah yaitu:

1. Al-Qur'an, surat Yusuf: 79

"Berkata Yusuf: "Aku mohon perlindungan kepada Allah daripada menahan seorang, kecuali orang yang Kami ketemukan harta benda Kami padanya, jika Kami berbuat demikian, Maka benar-benarlah Kami orangorang yang zalim".

2. Hadis Nabi riwayat Bukhari:

"Penanggung itu mennggung kerugian". (HR. Ibnu Majah dan Tirmidzi). ${ }^{44}$

Dalam hal ini ada beberapa pembagian tentang kafālah, diantaranya adalah:

a) Kafälah bin-nafs (الكفالة با النفس )

Kafälah bin-nafs merupakan akad memberikan jaminan atas diri (Personal Quarantee)

b) Kafälah bil-māl ( الكفالة بالما ل

Kafälah bi-māl merupakan jaminan pembayaran barang atau pelunasan utang.

c) Kafälab bit-taslim (الكفالة با التسليم)

Jenis kafälah ini biasa dilakukan untuk menjamin pengembalian atas barang yang disewa pada waktu masa sewa berakhir.

d) Kafälah al-Munjazah (الكفالة المنجزة)

Kafälah al-munjazah adalah jaminan mutlak yang tidak dibatasi oleh jangka waktu dan untuk kepentingan/tujuan tertentu. Salah satu

43 Imam Taqiyuddin Abu Bakar Bin Muhammad Al-Husaini, Kifayatul Akhyar, alih bahasa K.H. Syafruddin Anwar dan K.H. Mishbah Musthafa, cet., kedua, jilid., 1, (Surabaya:CV. Bina Iman), 1995, hal.

${ }^{4}$ Ibnu Rusyd, "Bidayatul Mujtahid Analisa Fiqih Para Mujtahid", Cet. III, Jilid. 3, Jakarta : Pustaka Amani), 2007, hal. 252. 
bentuk al-kafälah al-munjazah adalah pemberian jaminan dalam bentuk Performance bonds "jaminan prestasi", suatu hal yang lazim di kalangan perbankan dalam hal ini sesuai dengan bentuk akad ini.

e) Kafälah al-Mu'allaqah (الكفالة المعلقة)

Bentuk jaminan ini merupakan penyederhanaan dari kafälah almunjazah, baik dalam industri perbankan maupun asuransi. ${ }^{45}$

\section{Hukum Waris Menurut KUHPerdata}

Wirjono Prodjodikoro, mantan Mahkamah Agung Republik Indonesia, mengatakan: "Bahwa Hukum Waris adalah hukum-hukum atau peraturan-peraturan yang mengatur, tentang apakah dan bagaimanakah pelbagai hak-hak dan kewajiban tentang kekayaan seseorang pada waktu ia meninggal dunia akan beralih kepada orang lain yang masih hidup". Sedangkan Subekti dalam Pokok-pokok Hukum perdata tidak menyebutkan defenisi hukum kewarisan, hanya beliau mengatakan asas hukum waris, menurut Subekti: "Dalam Hukum Waris KUHPerdata berlaku suatu asas, bahwa hanyalah hak-hak dan kewajibankewajiban dalam lapangan hukum kekayaan harta benda saja yang dapat diwariskan.oleh karena itu hak-hak dan kewajiban-kewajiban dalam hukum lapangan kekeluargaan pada umumnya hak-hak dan kewajibankewajiban kepribadian misalnya hak-hak dan kewajiban sebagai suami atau sebagai ayah tidak dapat diwariskan, begitu pula hak-hak dan kewajiban-kewajiban seorang sebagai anggota sesuatu perkumpulan". ${ }^{46}$

Menurut Wirjono Prodjodikoro, bahwa pengertian kewarisan menurut KUHPerdata memperlihatkan unsur, yaitu:

a. Seorang peninggal warisan atau "erflater" yang pada wafatnya meninggalkan kekayaan. Unsur pertama ini menimbulkan persoalan, bagaimana dan sampai mana hubungan seseorang peninggal warisan dengan kekayaannya dipengaruhi oleh sifat lingkungan kekeluargaan, dimana si peninggal warisan berada;

b. Seseorang atau beberapa ahli waris (erfgenaam) yang berhak menerima kekayaan yang ditinggalkan itu, menimbulkan persoalan bagaimana dan sampai di mana harus ada tali kekeluargaan antara peninggal dan ahli waris agar kekayaan si peninggal warisan dapat beralih kepada si ahli waris;

\footnotetext{
45 Muhammad Syafi'I Antonio, Bank Syari'ah, cet. 1, (Jakarta: Gema Insani, 2001), hlm. 124-125.

46 Subekti, Pokok-Pokok Hukum Perdata, cetakan ke XIX, (Jakarta : Intermasa, 1984), hal. 95

dan 96.
} 
c. Hata warisan (balatenschap), yaitu wujud kekayaan yang ditinggalkan dan sekali beralih kepada ahli waris itu; menimbulkan persoalan, bagaimana dan sampai di mana wujud kekayaan yang beralih itu, dipengaruhi oleh sifat lingkungan kekeluargaan, di mana si peninggal warisan dan ahli waris bersama-sam berada. ${ }^{47}$

\section{Tinjauan Umum Tentang Pelimpahan Utang}

\section{Pembaharuan Utang (Novasi)}

Pembaharuan utang atau novasi diatur dalam Buku III Bab IV Bagian Ketiga KUHPerdata mulai Pasal 1413 sampai dengan Pasal 1424 KUHPerdata.

Pembaharuan utang (novasi) adalah suatu perjanjian antara debitor dan kreditor, di mana perjanjian lama dan subjeknya yang ada dihapuskan dan timbul sebuah objek dan subjek perjanjian yang baru. ${ }^{48}$

Ada empat unsur yang harus dipenuhi agar novasi dikatakn sah, yaitu:

1) Adanya perjanjian baru;

2) Adanya subjek yang baru;

3) Adanya hak dan kewajiban;

4) Adanya prestasi; ${ }^{49}$

\section{Macam-macam novasi ialah:}

1) Novasi Objektif

Ialah novasi dimana perikatan yang telah ada diganti dengan perikatan lain. ${ }^{50}$

2) Novasi Subjektif

Untuk novasi subjektif ini terbagi menjadi dua, yaitu:

a) Novasi subjektif aktif, adalah suatu novasi dimana krediturnya diganti oleh kreditur lain. Novasi ini selalu merupakan perjanjian segi tiga, karena debitur perlu mengikatkan dirinya dengan kreditur baru.

b) Novasi subjektif pasif, adalah suatu novasidimana debiturnya diganti oleh debitur lain. ${ }^{51}$

Pembaharuan utang atau novaasi itu pada hakekatnya merupakan suatu perjanjian baru untuk menggantikan yang lama, sehingga segala

\footnotetext{
47 Wirjono Prodjodikoro, Hukum Warisan di Indonesia, (Bandung : ‘s Gravenhage : Vorkink van Hoeve, 1962), hal. 9.

48 Salim HS, Pengantar Hukum Perdata Tertulis (BW),... hal. 193.

${ }^{49}$ Ibid, hal. 193.

${ }^{50}$ Ibid, hal. 193.

${ }^{51}$ Ibid, hal. 194.
} 
sesuatu yang ada sangkut pautnya dengan utang yang lama (misalnya: gadai, hipotik, bortog borg) tidak ikut berpindah, kecuali apabila hal tersebut secara tegas dipertahankan oleh si berpiutang. ${ }^{52}$

Menurut Pasal 1413 KUHPerdata ada 3 macam jalan untuk melaksanakan pembaharuan utang atau novasi, yaitu:

- Apabila seorang yang berutang membuat suatu perikatan utang baru guna orang yang mengutangkan kepadanya, yang menggantikan utang yang lama, yang dihapuskan karenanya.

- Apabila seorang berutang baruditunjuk untuk menggantikan orang berutang lama, yang oleh si berpiutang dibebaskan dari perikatannya.

- Apabila sebagai akibat suatu persetujuan baru, seeorang berpiutang baru ditunjuk dengan menggantika orang berpiutang lama, terhadap siapa si berutang dibebaskan dari perikatannya..$^{53}$

Secara umum dapat dikatakan pembaharuan utang adalah pembentukan perikatan baru berdasarkan pada suatu bentuk perikatan yang berdasarkan pada Pasal 1320 KUHPerdata. Syarat-syarat pembaharuan utang diatur dalam Pasal 1414 KUHPerdta yang menyatakan bahwa "pembaharuan utang hanya dapat terlaksana antara orang-orang yang cakap perikatan". Pasal 1414 KUHPerdata ini pada dasarnya merupakan penegasan kembali akan berlakunya ketentuan Pasal 1320 angka 2 KUHPerdata yang menyatakan "kecakapan untuk melakukan perikatan". ${ }^{54}$

Kehendak dan pelaksanaan novasi harus dinyataka secara tegas sebagaimana diatur dalam Pasal 1415 KUHPerdata yang menyatakan "tiada pembaharuan utang yang dipersangkahkan, kehendak seseorang untuk mengadakan harus dengan tegas ternyata dari perbuatannya. Ini berarti suatu pembaharuan utang harus dengan tegas menyatakan bahwa utang lama atau perikatan lama diantara debitur dan kreditur menjadi hapus demi hukum dan sebagai penggantinya dibuat dan diberlakukan perikatan yang baru dengan syarat-syarat dan ketentuan yang baru. ${ }^{55}$

Kreditur tidak dapat menuntut debitur dari dibebaskan hutangnya diatur dalam Pasal 1418 KUHPerdata menyatakan bahwa "si berpiutang yang membebaskan berutang yang telah melakukan pemindahan, tidak dapat menuntut orang tersebut, jika orang yang ditunjuk untuk menggantikan itu jatuh dalam keadaan pailit atau benar-benar tidak

\footnotetext{
52 Ibid, hal. 205.

${ }^{53}$ Komariah, Hukum Perdata, (Malang : UMM Press, 2008), hal. 204.

54 Ibid., hal 204.

${ }^{55}$ Karti Muljadi dan Gunawan Widjaja, Seri Hukum Kekayaan Hak Tanggungan, Jakarta : Prenada Media, 2005), hal. 234.
} 
mampu, terkecuali jika hak penuntutan itu dengan tegas dipertahankan dengan persetujuan, atau jika orang yang berutang yang ditunjuk sebagai pengganti itu pada saat pemindahannya telah nyata-nyata bangkrut, atau dalam keadaan yang terus menerus merosot kekayaannya.

Keberadaan hak tanggungan melekat pada perikatan pokok atau perjanjian kredit setelah adanya pembaharuan utang atau novasi adalah:

a. Pada novasi objektif, tanpa penggantian kreditor dan debitor, maka untuk tetap mempertahankan hak tanggungan yang telah dibebankan, maka dalam perjanjian pembaharuan atas perikatan lama, perlu ditegaskan kembali maksud untuk tetap mempertahankan hak tanggungan yang telah ada dan telah diberikan tersebut;

b. Pada novasi subjektif aktif, dengan pergantian kreditor, hal sama, yaitu bahwa dalam perjanjian pembaharuan utang harus dicantumkan dengan tegas maksud dari para pihak untuk tetap mempertahankan hak tanggungan yang telah dibebankan, agar hak tanggungan yang telah ada tetap dapat dipertahankan, tanpa kehilangan eksistensinya;

c. Pada novasi subjektif pasif, dengan pergantian debitor, maka demi hukum hak tanggungan hapus, kecuali dalam hal debitor baru menggantikan debitor lama adalah juga pemberi hak tanggungan dalam perikatan pokok yang dihapus dengan perikatan tersebut, maka untuk mempertahankan hak tanggungan yang telah diberikan tersebut, dalam perjanjian pembaharuan utang harus dicantumkan dengan tegas maksud dari para pihak untuk tetap mempertahankan hak tanggungan yang telah dibebankan, agar hak tanggungan yang telah ada tetap dapat dipertahankan, tanpa kehilangan eksistensinya. ${ }^{56}$

\section{Pelimpahan Hutang Pewaris Perspektif KUHPerdata dan Hukum Islam}

Berdasarkan hukum perdata berlaku Pasal 833 ayat (1) Kitab Undang-Undang Hukum Perdata. Pasal tersebut menyatakan bahwa "para ahli waris dengan sendirinya karena hukum, mendapat hak milik atas semua barang, semua hak dan semua piutang orang yang meninggal". Sehingga ahli waris tidak hanya akan mendapatkan harta warisan saja melainkan ia akan diwajibkan untuk melunasi semua hutanghutang pewaris.

Hakekat dalam KUHPerdata bahwa hutang-hutang si pewaris beralih pula kepada ahli waris juga menentukan bahwa para ahli waris dapat menghindarkan peralihan itu dengan jalan menerima atau menolak

${ }^{56}$ Ibid, hal. 235. 
warisan atau menerima dengan syarat, yaitu menerima tetapi dengan ketentuan ia tidak akan diwajibkan membayar hutang si pewaris yang melebihi bagiannya dalam warisan itu.

Dengan demikian KUHPerdata mengenal 3 macam sikap dari ahli waris terhadap harta warisan, yakni:

1. Ia dapat menerima harta warisan seluruhnya menurut hakekat tersebut dari KUHPerdata, termasuk seluruh hutang si pewaris.

2. Ia dapat menolak harta warisan dengan akibat bahwa ia sama sekali tidak tahu menahu tentang pengurusan harta warisan itu.

3. Ia dapat menerima harta warisan dengan syarat bahwa harus diperinci barang-barangnya dengan pengertian bahwa hutang-hutang hanya dapat ditagih sekedar harta warisan mencukupi untuk itu.

Oleh karena pemilihan satu dari tiga sikap tersebut di atas dapat berpengaruh besar terhadap ahli waris, maka oleh KUHPerdata kepada mereka secara tegas diberi kesempatan untuk berpikir dahulu sebelum memilih salah satu sikap itu. Hak-hak berpikir ini diatur dalam pasal 1023 sampai pasal 1029 KUHPerdata.

Dalam pasal 1100 KUHPerdata yang berbunyi "kewajiban melakukan pembayaran tersebut dipikul secara perseorangan, dan masing-masing menurut jumlah besar bagiannya, satu dan lain dengan tidak mengurangi hak-hak para berpiutang atas seluruh harta peninggalan selama harta itu belum terbagi dan tidak pula mengurangi pula hak-hak para berpiutang hipotik".

Ketentuan pasal 1100 KUHPerdata dan pasal 1104 harus dilaksanakan dengan mengingat kepada beberapa syarat, yaitu pertama, bahwa ahli waris yang lain baru wajib turut memikul kelebihan tanggungan ahli waris yang melunasi hutang, kalau hutang yang dilunasi hutang warisan; kedua, pasal 1104 KUHPerdata baru diterapkan kalau ada ahli waris yang pada saat pelunasan hutang warisan jatuh pada keadaan tidak mampu. Maksudnya kalau sampai terjadi, bahwa pada saat ahli waris yang menerima benda warisan dalam keadaan memikul beban melunasi hutang warisan dan ahli waris yang lain dalam keadaan mampu, tetapi karena kelalian hali waris itu, ahli waris yang lain tidak segera ditagih sehingga dikemudian hari karena perubahan keadaan pada waktu ditagih, ahli waris tersebut jatuh dalam keadaan tidak mampu, maka resiko itu tidak bisa dilimpahkan kesemua ahli waris yang lain bersamasama dengan ahli waris yang membayar.

Sedangkan untuk pelimpahan atau peralihan hutang didalam hukum Islam dinamakan biwalah, yakni pengalihan hutang dari orang yang berhutang kepada orang lain yang wajib menanggungnya. Dalam istilah para ulama, hal ini merupakan pemindahan beban hutang dari 
mübil (orang yang berhutang) menjadi tanggungan mühal 'alaih atau orang yang berkewajiban membayar hutang. ${ }^{57}$

jika ada seseorang yang berhutang meng-hiwälah-kan kepada orang yang kaya/mampu, hendaklah ia menerima biwälah tersebut dan hendaknya ia menagih kepada orang yang di-biwälab-kan (mübal 'alaib). Dengan demikian, orang pertama yang berhutang tadi tidak diwajibkan untuk membayar hutangnya, sebab hutang tersebut telah beralih kepada orang yang menanggungnya.

Sebagian ulama berpendapat bahwa perintah untuk menerima biwālah adalah wajib. Oleh sebab itu, wajib bagi orang mengutangkan (mühal) menerima biwālah. Adapun mayoritas ulama berpendapat bahwa perintah untuk menerima hiwālah itu adalah sunnah. Jadi, sunnah hukumnya menerima hiwälah bagi mühal. Karena hal ini didasari oleh sebuah hadits imam Imam Bukhari dan Muslim meriwayatkan dari Abu Hurairah bahwa Rasulullah saw, bersabda:

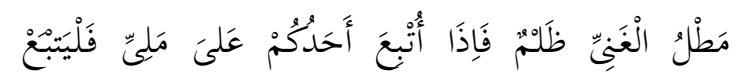

"Menunda pembayaran bagi orang yang mampu adalah suatu kezaliman. Dan, jika salah seorang dari kamu diikutkan (di-hawalab-kan)kepada orang yang mampu/kaya, terimalah hawalah itu."

Didalalam hukum Islam hiwālah seringkali dikaitkan dengan adanya dāman (jaminan) dan kafälah (tanggungan). Jika dilihat dari pengertian keduanya, maka kedua hal tersebut fungsinya sama dengan biwālah. Karena dāman dan kafälah adalah adanya suatu jaminan untuk menanggung semua hak dan kewajiban untuk memenunhi tanggungan orang lain. Didalam pembahasan warisan baik secara KUHPerdata maupun hukum Islam ada beberapa hak dan kewajiban bagi ahli waris yang menerima warisan. Diantara salah satunya adalah ahli waris diwajibkan melunasi semua hutang-hutang pewaris hutang yang semasa pewaris masih hidup. Hutang tersebut akan dilunasi dengan menggunakan harta peninggalan si pewaris. Akan tetapi, jika masalah yang akan timbul adalah hutang lebih besar dari pada harta warisan, maka secara KUHPerdata memberikan suatu jalan kepada ahli waris untuk mengambil sikap penolakan warisan. Sehingga ahli waris tidak akan tahu menahu tentang pembagian harta warisan, dan juga ahli waris yang menolak warisan tersebut tidak akan dibebani dengan adanya semua hutang-hutang si pewaris. Dalam hal ini sedikit berbeda dengan hukum Islam yang mempunyai konsep peralihan hutang terhadap ahli waris

${ }^{57}$ Fatchur Rachman, Ilmu Waris, (Bandung : Al Maarif, 1975), hal. 70. 
ataupun orang lain yang mampu untuk menanggung semua hutang dari pewaris tersebut. Sebab, hutang adalah sebuah kewajiban bagi setiap orang yang berhutang untuk melunasi semua hutang-hutangnya.

\section{Penutup}

Pelimpahan hutang sebagai warisan memang merupakan hal yang menarik untuk dibahas, dan hukum islam serta KUHPerdata juga telah memberikan analisis dan argument terkait hal tersebut sehingga masyarakat sebagai pelaku di bidang keperdataan dapat mengambil sikap terhadap hal-hal yang berkaitan dengannya. 


\section{Daftar Pustaka}

Al-Husaini. Imam Taqiyuddin Abu Bakar Bin Muhammad, Kifayatul Akhyar, alih bahasa K.H. Syafruddin Anwar dan K.H. Mishbah Musthafa, cet., kedua, jilid., 1, (Surabaya:CV. Bina Iman)

Andasamita. Komar, Notaries III Hukum Harta Perkawinan dan Waris, (Ikatan Notaris Indonesia Daerah Jawa Barat, 1987)

Antonio. Muhammad Syafi'i, Bank Syari'ah, cet. 1, (Jakarta: Gema Insani, 2001)

Ash Shiddieqy. T.M. Hasbi, Fiqhul Mawaris (Hukum-Hukum Warisan Dalam Syari'at Islam), (Jakarta : Bulan Bintang, 1973)

Badrulzaman. Mariam Darus, dan Ali, Kompilasi Hukum Perikatan, (Bandung : PT. Citra Aditya Bakti, 1997)

Fachrodin, F. (2019). Fungsi Hukum dalam Pembangunan Ekonomi.

Tafáqquh: Jurnal Penelitian Dan Kajian Keislaman, 7(1), 114 138.

HS. Salim, Pengantar Hukum Perdata Tertulis (BW)

http://id.shvoong.com/humanities/religion-studies/2148108-macammacam-hiwālah/\#ixzz20kat4yur, diakses 21 Agustus 2012.

http://id.shvoong.com/humanities/religion-studies/2148108-macammacam-hiwālah/\#ixzz20kat4yur, diakses 21 Agustus 2012.

Komite Fakultas Syariah Universitas Al-Azhar Mesir, Hukum Waris Islam, (Jakarta: Senayan Abadi Publishing, 2004)

Komariah, Hukum Perdata, (Malang: UMM Press, 2008)

Muchlas. Imam, Waris Mewaris dalam Islam, cet. I, hal. 2, (Pasuruan : PT. Garoeda Buana Indah, 1996), hal. 3. dikutip dari Sayuti Thalib, Hamid Farihi, Pembaharuan Hukum Kewarisan Islam di Indonesia, Studia Islamika,(Jakarta : 18 Nopember 1983)

Muljadi. Karti, dan Gunawan Widjaja, Seri Hukum Kekayaan Hak Tanggungan, Jakarta : Prenada Media, 2005)

Pilto. A, Hukum Waris, Menurut Kitab Undang-Undang Hukum Perdata Belanda, Jilid II, dialih bahasakan oleh M. Isa Arief, Jakarta : PT. Intermasa,1986)

Prodjodikoro. Wirjono, Hukum Warisan di Indonesia, (Bandung : 's Gravenhage : Vorkink van Hoeve, 1962)

Rachman. Fatchur, Ilmu Waris, (Bandung : Al Maarif, 1975)

Ramulyo. M. Idris, Perbandingan Pelaksanaan Hukum Kewarisan Islam dengan Kewarisan menurut Hukum perdata (BW), edisi kedua, cetakan kedua, (Jakarta : Sinar Grafika, 2000) 
Rofiq. Akhmad, "Hukum Islam di Indonesia", cetakan 3,(Jakarta: PT.Grafindo, 1998)

Rusyd. Ibnu, "Bidayatul Mujtahid Analisa Fiqih Para Mujtahid", Cet. III, Jilid. 3, (Jakarta : Pustaka Amani, 2007)

Sabiq. Sayyid, Fiqih Sunnah, alih bahasa Nor Hasanuddin, cet. I, jilid. 4. (Surabaya:CV. Bina Iman, 1995), hal. 223.

Salman. Otje, dan Mustofa Haffas, Hukum Waris Islam,(Bandung : Refika Aditama, 2001)

Subekti, Pokok-Pokok Hukum Perdata, cetakan ke XIX, Jakarta : Intermasa, 1984)

Suparman. Eman, "Hukum Waris Indonesia", (Bandung : PT. Refika Aditama, 2007)

Syarifuddin. Amir, HukumKewarisan Islam, (Jakarta : Kencana, 2008)

Syuhada. (2020). Penerapan Bagian Warisan Anak Perempuan Dan Cucu: (Studi kasus KHI pasal 176). Tafáqquh: Jurnal Penelitian Dan Kajian Keislaman, 8(2), 286-301 